\title{
Kathryn Knight
}

\section{Writing dislocation and disruption: The strange country of mothers of children with disabilities}

\begin{abstract}
The sociocultural narratives available to mothers of children with disabilities exhort them to resist the impacts of their exclusion from mainstream discourses of motherhood, perform resilience, and re-interpret their marginalisation as a 'different kind' of mothering: a re-location. Such narratives function to suppress the complex emotions associated with the profound sense of dislocation experienced by these mothers. Two short pieces of writing are discussed, both of which use geographical metaphors to represent the competing themes of emotional containment versus disruption; the first is a tale widely circulated among families of children with disabilities, and the second is a memoir piece by the author. This discussion draws on the emergent literature by mothers of children with disability and academic research on families of children with disabilities, as well as on insights from Friedman's work on the geographics of identity. The mother who seeks to write about her own dislocation must be prepared to speak against the dominant scripts that work to deny her emotional responses, while her own entitlement to self-represent is challenged by the compounded impacts of the discourses surrounding motherhood and disability.

Keywords: mothers of children with disabilities, disability life writing, motherhood narratives
\end{abstract}

\section{Introduction}

Mothers of children with disabilities are often thought of as performing a 'different kind of mothering' (Ryan \& Runswick-Cole 2009). We share the same neighbourhoods as mainstream mothers, but the sites we inhabit physical, social, emotional - are different. When we walk through familiar streets and local shopping malls with our children, we are often stared at as if we were foreigners. While we live among other families, our place is not the same; as Skinner and Weisner explain: 'Place means not only the geographic locale and ecology, but the local community and its resources and ways of life, and its shared beliefs about development and disability' (Skinner \& Weisner 2007: 302). Ours is a strange country.

Our relationships with our children are different, not because we love them any more or less, but because the level of care we are obliged to give is far more intensive, and much longer-term. We are subject to the same mythologies and regimes of surveillance as other mothers, but with a level of expectation and rigour that exceeds that imposed on mainstream mothers, leading to Read's 
observation that mothers of children with disabilities are 'distilled and magnified versions of motherhood' (Read 2000: 107).

Our stories are different, too. When a woman becomes a mother, she is necessarily interpellated by the repertoire of cultural narratives of motherhood. But when our children are diagnosed with a disability, our entitlement to appropriate these narratives is threatened. Other stories of borderland motherhood replace those from the mainstream, and like all narratives of motherhood, ours set out to instruct, reward and admonish, as well as, or instead of, truth-telling. As the mother of an adult daughter with a severe intellectual disability, I have been immersed for 25 years in the narratives of motherhood and child disability. These social scripts work to situate me outside the mainstream; some punish me with discourses of blame (Landsman 2009), or exoticise me with accolades of my specialness (Read 2000). Many exhort me to overcome my experience of difference, to 'renorm the normal' (Raspberry \& Skinner 2007), and to enact resilience on behalf of my child and family (Grant \& Ramcharan 2001). Others encourage me to forge an identity as an activist on behalf of my child, so that I can reclaim a self-image as a 'good' mother (Landsman 2005; Ryan \& Runswick-Cole 2008, McKeever \& Miller 2004). Some direct me to reach beyond this goal, to work toward transforming myself to become a better human being (Dykens 2005, Grant et al 2007). And there are those that counsel me to take up a moral purpose, that of re-asserting the personhood of my child in a culture that has devalued her (Frank 2004). The tension caused by performing this psychic work while managing exclusionary discourses about motherhood and disability is a feature of the strange country that mothers like me inhabit.

In order to write her own story, the mother of a child with disability needs to locate her own lived experience somewhere within the range of these cultural scripts. Frank (2010) has coined the term narrative habitus (borrowing from Bourdieu) to describe the repertoire of sociocultural scripts or stories that are available to an individual. Narrative habitus, he writes, is 'the unchosen force in any choice to be interpellated by a story' (Frank 2010: 53). These scripts are powerful; they encode and rehearse the accepted parameters of identity. But while these available narratives provide templates for the stories that may be told and heard, they also exert power and control by identifying those that are deemed legitimate. As such, they serve a socio-political function, by disprivileging counternarratives. Frank argues that while storytellers have the capacity to resist these prescribed narratives, such resistance is difficult, because the pre-existing scripts are so firmly entrenched in the narrative landscape, and divergence may be deemed transgressive. For the mother of a child with disability, resisting these sociocultural scripts presents compounded challenges because she is likely to feel disentitled, due to her marginalised status.

An underlying theme of these culturally approved narratives is containment: the management of dislocation, through redirection and re-placement. In order to explore this theme of containment along with its converse, disruption, I will discuss two short pieces of writing in which geographical metaphors are used in two very different ways to represent the sense of dislocation experienced by mothers of children with disabilities. The first of these is a tale by the mother of a child with a disability who at the time of writing was scriptwriter for a wellknown US children's television program. Written in the 1980s, this parable continues to be circulated in sociocultural sites across the Anglophone world where parents of young children with disabilities interact. The themes of this tale are containment and normalisation. In contrast, the second piece gives testimony to the emotional disruption that continues to threaten such efforts of 
containment. This is a fragment of memoir, a recount of a dream, written by me twenty years into my 'different' mothering experience.

In this discussion, I draw on the small but emergent literature by and about mothers of children with disability; and on social science studies of families of children with disabilities, which is the largest body of research on this topic. I am guided by Susan Stanford Friedman's theoretical work on the geographics of identity (1998). Central to this discussion is my own project of writing about my own experience of mothering a child with a disability.

\section{Narratives from the academic literature}

Academic literature that addresses the impacts of child disability on the family is a rich source of narratives about mothers, and a valuable site for exploration. Over the past forty years, research coming out of the health and social sciences has reflected shifts in social and political positions surrounding disability and care-giving. The narratives that emerge from this research are not simply reflective, however: they play a constitutive role in in shaping social attitudes and behaviours, and in informing human services policy. While the subjects of this research are purportedly families of children with disabilities, it is, in effect, mothers who typically come under the microscope in this literature (Turnbull et al 2007).

The beginnings of this research in the 1970s coincided with the widespread deinstitutionalisation of people with disabilities throughout the western world. Prior to that time, children with disabilities (particularly intellectual disability) were commonly institutionalised: parents were encouraged by authorities to place their child in a 'home' so they could get on with normal family life. Mental retardation, as intellectual disability was referred to at that time, was, as Fewell observed in 1986, 'probably the most dreadful diagnosis a parent can receive' (cited in Shapiro, Blacher \& Lopez 1998: 606). This early research focused on the identification of 'caregiver burden' (Grant \& Ramcharan 2001), and these studies 'presented a bleak picture of stress, burden, depression, social isolation and psychological dysfunction' (Shapiro, Blacher \& Lopez 1998: 606).

A paradigm shift occurred around 2000, the result of several converging factors, including new strengths-based approaches to family studies in general (Grant \& Ramcharan 2001), and the impacts of the disability rights movement, which challenged the belief that disability was synonymous with family tragedy. Through these new narratives, researchers were now valorising the performance of resilience; they placed emphasis on measuring the coping capacities of families, with the spotlight firmly on mothers. Findings typically reported on the capacity of mothers to mobilise what Hastings and others have termed 'positive reframing coping strategies', or the ability of the mother to reinterpret this potentially disruptive experience in advantageous ways on behalf of the child and family. According to these researchers, 'Having a child with more severe disabilities may provide mothers with more opportunities to grow personally and develop a mature outlook on the world due to the increased challenges posed' (Hastings et al 2002: 273). Over the past decade, this theme has dominated the health and behavioural studies literature, as illustrated by the titles of several recently published articles: 'Accentuate the positive to mitigate the negative' (Trute et al 2010), 'Happiness, wellbeing and character strengths' (Dykens 2005), and 'Children with intellectual disability: A gain not a loss' (Dura-Vila et al 2010). Several researchers have taken this narrative of personal growth through adversity further, by proposing the term 
'transformational coping' to describe this potential for psychic enrichment. Grant, Ramcharan and Flynn (2007), for example, describe the commitment to the vocation of care-giving that exemplary mothers of children with disabilities exhibit, as evidence of this transformational journey.

An alternative body of research has also emerged during the past decade, coming out of critical disability studies. This work foregrounds the complex socio-political context in which mothers of children with disabilities negotiate the challenged identities of themselves and their children. While the theme of the research discussed above could be summarised as 'resilience', these sociocultural studies are characterised by narratives of 'resistance'. Goodley (2007), for example, draws on the work of Deleuze and Guattari to claim that parents of children with disabilities behave as rhizomes: 'They shift, forever move, along non-hierarchical networks... Ignore trees and think of nature and of weeds, grass, swarms and packs of rats' (Goodley 2007: 149). Engaged in a continual process of resisting, parents are nomadic, in a perpetual state of becoming, manoeuvring around the dominant discourses of disability that seek to constrain them. Landsman (2005) describes the way mothers must negotiate through competing discourses about disability - medicalised accounts that pathologise the child and the family, versus the rhetoric of social inclusion and empowerment - that confront them as their child grows, and how the need to reconcile these different positions reinforces their sense of dislocation. McKeever and Miller (2004) refer to the work of Bourdieu in their discussion of how mothers of young children with severe disabilities feel pressure to increase the social value of their children and themselves in encounters with medical personnel. Todd and Jones (2003) describe the 'disciplinary gaze' (after Foucault) that falls upon mothers in these encounters with professionals; mothers enact resistance to this through becoming activists on behalf of their children. Similarly, Ryan and Runswick-Cole (2009) argue that the performance of advocacy and activism on behalf of their children enables mothers to reclaim a valued identity for themselves "while at the same time managing their image as the "selfless carer" (Ryan \& Runswick-Cole 2009: $51)$.

These two streams of research have produced narratives that contrast with each other, but also converge in one key way. The behavioural studies are concerned with the psychological characteristics that enable the individual mother to adjust to and overcome her stigmatised identity. The sociocultural studies, on the other hand, acknowledge the contextual issues that inform the sense of exclusion experienced by mothers and their families, and explore the ways in which mothers perform resistance. For researchers from both streams, however, the mother is the agent upon whom responsibility for the containment of disruption and management of dislocation falls.

Much less attention in the literature has been devoted to exploring the psychic impact on the mother of giving birth to a child with disability. Those researchers who do address this issue have told of the 'disruption' to '[the mother's] global interpretation of life's events' (Trute et al 2010) caused by such a transgression of the cultural norms of motherhood. This disruption functions as a turning point 'in which mothers may experience an anomic period in which the ways they have made sense of the world and dominant norms and values that guide their understandings are no longer relevant' (Ryan \& Runswick-Cole 2008: 203). These authors acknowledge the depth of the emotional crisis that a mother faces when she confronts her own transgression. But the narratives available to her give her little opportunity to process her displacement; instead, she is channeled into more sanitising responses. 
It could be argued that the negative psychological impact on the mother is mitigated today by a much more positive sociocultural attitude to disability. But this positive change has been to a large extent overridden by current medical discourses surrounding pregnancy. As Landsman argues, the increased technological surveillance of pregnancy, with its heavy emphasis on maternal responsibility, reinforces messages of mother-blame (Landsman 2009). Once, the womb was seen as a safe haven for the developing foetus, Landsman writes, but today it is seen as 'permeable, vulnerable to the dangers delivered by selfish, careless women' (2009: 86). Mothers of children with disabilities are frequently subjected to interrogation by medical personnel following the diagnosis of their child as doctors attempt to unravel the mystery of her child's condition and tacitly imply her culpability (Knight 2013). In Landsman's study of mothers of children with disabilities, she found that all participants engaged in a process of systematic self-blaming for their child's condition, even though any such link was unproven in all cases (2009: 23). Blame, guilt and selfadmonishment are part of the substrate of this strange country.

\section{'Welcome to Holland': Dislocation, redirection and containment}

'Welcome to Holland', the first text for consideration, is a short narrative that addresses the dislocation experienced by parents at the time of their child's diagnosis of disability. Written in 1987 by Emily Perl Kingsley, mother of a child with a disability who is perhaps better known as a Sesame Street scriptwriter, this parable teaches parents about making the best of landing in the foreign territory where they now unexpectedly find themselves. It continues to appear frequently on the noticeboards of hospital wards and special schools, and in the newsletters of child disability service providers and advocacy groups throughout the English- speaking world. As such, it has emerged as a popular exemplary text that instructs parents on how to manage an ostensibly unmanageable experience in a way that is socially legitimate. It is included in anthologies of parental life writing (Klein \& Shive 2001); it is often alluded to in the memoirs of mothers of children with disabilities (Groneberg 2008; Evans 2007; Raca 2012); and it is cited by researchers (Rapp \& Ginsberg 2001; Goodley 2007; and Kingston 2011). The story begins as follows:

I am often asked to describe the experience of raising a child with a disability - to try to help people who have not shared this experience to understand it, to imagine how it would feel. It's like this...

When you're going to have a baby, it's like planning a fabulous vacation trip - to Italy. You buy a bunch of guide books and make your wonderful plans. The Coliseum. Michelangelo's David. The gondolas in Venice. You may learn some handy phrases in Italian. It's all very exciting.

After months of eager anticipation, the day finally arrives. You pack your bags and off you go. Several hours later, the plane lands. The stewardess comes in and says, 'Welcome to Holland'.

'Holland?' you say. 'What do you mean Holland? I signed up for Italy! I'm supposed to be in Italy. All my life I've dreamed of going to Italy.'

But there's been a change in the flight plan. They've landed in Holland and there you must stay.

The important thing is that they haven't taken you to a horrible, disgusting, filthy place full of pestilence, famine, and disease. It's just a different place. 
So you must go out and buy new guidebooks. And you must learn a whole new language. And you will meet a whole new group of people you would never have met. (Kingsley 2001)

Kingsley goes on to explain that while Holland may not be as 'flashy' as Italy, it has its own charms: windmills, tulips, even Rembrandts. She counsels that while the pain of losing your dream of travelling to Italy may never go away, you cannot spend your life mourning this loss, because "you may never be free to enjoy the very special, the very lovely things ... about Holland'.

Regarding this tale, Rapp and Ginsberg write: 'It offers families of chronically ill and disabled children a parable of an unexpected journey to an unknown world, a counternarrative of hope in the face of the sense of crisis experienced by many families with hospitalised offspring' (Rapp \& Ginsberg 2004: 545). The popularity of this tale among parents, these authors claim, is evidence of their resistance to the scripts imposed on them and their children by medical and governmental regimes, and society at large: it provides 'a sense of reorientation to a place of possibility, as opposed to disappointment' (2004: $545)$.

When I first read this tale, however, not long after my daughter's disability was diagnosed when she was a baby, I was baffled. Why did Kingsley use the analogy of a vacation, which is time limited and comes with a return ticket home? No version of motherhood fits into that plotline. And how could she compare the dark place where I was with Holland as a tourist destination? Her story disturbed me: it seemed to trivialise the depth of my response, at all levels: cultural, social, emotional, biological. It provided me not with a sense of community or a place of refuge, but with a profound apprehension of alienation, based on a fear that my own reaction to this crisis was as aberrant as my delivery of a severely disabled child. At that time of deep vulnerability, Kingsley's tale struck me as particularly insensitive, with its subtext of reducing and containing my experience. It worried me, too, that there might be others like me who did not have the emotional and cognitive resources to reinterpret this all as a simple change of destination.

In Kingsley's narrative, the hapless passengers on the flight are sent somewhere unexpected, and are counselled to make the best of it. They express some indignation about this upset, but this is a fleeting response. Any memory of the turbulence that led to this unplanned crossing of borders goes unreported, and this disremembering is central to the message of this tale. The powerful emotions of grief, guilt, anger, confusion and uncertainty that parents encounter when they make this crossing are pushed aside. And yet this disruption involves the passengers' entry into a place of fear: a liminal zone, a territory of chaos and formlessness, a threshold, where connections with the old order are threatened and may be severed, and there is no sign of a path forward. This is place is synonymous with the 'anomic period' described above by Ryan and Runswick-Cole (2008). Friedman (1998) uses the metaphors of 'nomadic wandering' and 'the lack of solid ground' (Friedman 1998: 19) to describe the subject's encounters with such a place of liminality. She contrasts the notion of 'organic wholeness' with the individual who, like the passengers, is in a state of 'spatialized flux' (1998: 3).

Instead, the passengers manage to bypass this zone, and cross the border into safe, albeit unplanned country. For Friedman, borders figure strongly in the negotiation of identity. 'Borders protect but they also confine,' she writes (1998: 3). These border crossings serve to segregate the passengers from mainstream holidaymakers, and relegate them to a place of difference. The new 
borders confine them, and mark them as other. But they also serve a protective function, by directing the travellers away from their psychic disruption. The emotions associated with this turbulence are potentially excessive; they are messy; they signify lack of control; they threaten maternal efficacy; and they interfere with medical and social regimes of remediation. Expressing these emotions is hazardous because such feelings imply doubts about the mother's capacity for unconditional love for and commitment to her child; they may be interpreted as selfish, and even unnatural.

The safe haven offered to the passengers avoids this chaos. While the tale's aim may be, as Rapp and Ginsberg (2004) claim, to provide parents of children with disabilities with reorientation to a place of possibility, it serves other purposes: to deny these unfathomable emotions and refuse the chaos that might be unleashed by them. In short, this disremembering serves to repress and contain. As Friedman points out, 'Borders enforce silence, miscommunication, misrecognition' (1998: 3).

The subjects of this story are parents, both mothers and fathers, and while fathers of children with disability also undergo disruption and dislocation, my focus is on mothers, because the embodied experience of mothers compounds their vulnerability: 'My own body was my son's first home,' writes Robertson (2012: 136). In contrast to this repression of emotion that underlies Kingsley's tale, mothers of children with disabilities who write memoirs often narrate their responses to their child's birth and diagnosis in vivid detail. These may be harrowing accounts of traumatic deliveries (Edelson 2000; Johannesen 2011; Raca 2012) and/or reactions to the news of their child's disability. Following her child's diagnosis with Down syndrome, journalist Kathy Evans writes: 'I have become afraid of my own body, cut off from it ... something deep inside, something from my own past, tells me it is my fault' (Evans 2007: 102). Canadian Miriam Edelson explains that 'My emotional response is a strong sense of failure and self-blame... I keep functioning because I must. But inside, I am shattered' (Edelson 2000: 46). Like Landsman's mothers referred to above, Edelson's feelings of guilt lead to ruminations: 'I dredge up harrowing scenarios from the pregnancy, like needing urgent dental work when a filling came out, or slipping on the ice one evening outside my office building' (45). Researchers, on the whole, ignore these maternal narratives, or when they do address them, they rebuke authors for their emotionalism. Piepmeier (2012), for example, argues that 'Excessive grief [in parental memoirs] functions to dehumanize the child by identifying the child as the source of almost unbearable sadness' (Piepmeier 2012). Piepmeier concedes, however, that authors typically turn a corner in these works, and negative emotions are eventually replaced with a sense of gratitude. Nevertheless, the expression of grief is largely disallowed by commentators; Robertson comments on how the positive reviews in the press elicited by Charlotte Moore's 2004 memoir about her disabled sons, George and Sam (Moore 2004), contrasts with the negative reception of more emotionally confronting testimonies: '[Moore's] uncomplaining, unemotional and matter of fact tone elicits admiration' (Robertson 2011: 6). Containing or erasing complex emotions in these stories renders them cleaned up and constrained, and consequently of limited value to both tellers and receivers. This containment serves to control the release of these unruly emotions for social purposes, quarantining this potential disruption away from mainstream family life and society at large. It also has a political function: mothers who are resilient and uncomplaining are disciplined subjects who personally bear the consequences of their own marginalisation.

Towards the end of the excerpt above, Kingsley dares to touch on the stigmatising potential of the passengers' unexpected destination, but at the same time she refuses it: 'The important thing is that they haven't taken you to 
a horrible, disgusting, filthy place full of pestilence, famine, and disease. It's just a different place' [1]. This 'disgusting, filthy place' may be interpreted as a metaphor for the dominant sociocultural response to the transgression that is disability. Shakespeare, for example, has referred to the cultural representation of people with disability as 'dustbins for disavowal' (Shakespeare 1994). As Lewiecki-Wilson and Cellio assert, the liminal space inhabited by those marginalised by disability, is:

dangerous, dirty, threatening to all categories. In a society that values the whole body, the stable identity, the independent subject, the liminal state represents the erratic, the variable, the unstable. In sum, the liminal processes of interdependent and shifting self and other are threatening, stigmatized, and associated with the fear of disability. (Lewiecki-Wilson \& Cellio 2011: 7)

The horrible place referred to is in fact the opposite of the new destination, Holland, which is synonymous with order and cleanliness, and culturally acceptable icons such as tulips and windmills.

Kingsley counsels the passengers to refuse this version, and along with it, the dominant culture's response to disability. Holland is a much more wholesome destination than the disgusting place the passengers might have been sent to. But this place cannot be easily sanitised; simply exhorting mothers of children with disabilities to refuse this narrative of marginalisation does not obliterate it. It plays a major role in the way they and their children are positioned by the dominant culture: it impacts their lived emotional reality, and it informs social and political attitudes to them. It cannot be simply ignored, or repaired with their efforts of cognitive re-framing.

Kingsley's tale has been repeated and reproduced often by parents of children with disabilities, and by scholars who praise the values of resilience and resistance that it expresses. But underlying these messages are the much darker themes of marginalised identities, containment and repression.

\section{Inhabiting the liminal spaces: 'Der Traum'}

While borders serve to separate and confine, Friedman asserts that the borderlands occupied by marginalised people may indeed be fertile sites for exploration: for interrogating dominant scripts and re-negotiating identity. By engaging with the potential of these liminal spaces, by finding a voice and speaking from them, those who are marginalised may find ways of challenging mainstream emplotments, and making forays into new ways of selfrepresentation. In specifically addressing the marginalisation of those at the intersection of motherhood and disability, Liewicki-Wilson and Cellio also emphasise the productive capacity of these liminal spaces, where, they claim, 'resistance to cultural scripts and emergent knowledge can potentially arise' (Liewicki-Wilson \& Cellio 2011: 2). These authors call for engagement with the dark places of the borderlands, rather than repudiation of them. But they acknowledge that while such liminal spaces may be potentially generative, writing from them 'is also fraught with risks' (2011:6): the subject must be prepared to speak against the dominant scripts that work to erase her responses; and she must face the problem of mobilising language in a way that can effectively represent her experience.

The second piece of writing for discussion is an extract from my memoir of mothering my daughter who has a disability, 'Strange Country' [2]. Like 
'Welcome to Holland', this piece is located during a holiday trip to a European destination. It, too, is about dislocation, but it is situated at a different place in the maternal life cycle: my daughter is not a young child, but 21 years old. As such, it is set after two decades of stock-piling resources of resilience and resistance as a marginalised mother; of negotiating the boundaries between the world of disability and the mainstream world on behalf of my child and my family. It comes at a time when most mothers have long since stepped back from an intensive mothering role, when alternative options for performing identity are typically open to them. It comes at a time when my own passage through the liminal zones should be resolved. And yet I am revisited by this old disruption: it breaks through the boundaries to challenge my hard-won resistance. This time, its arrival is triggered by geographical dislocation in a place far from home, and it comes in the form of a dream.

The title of this piece involves a play on words: der Traum is German for 'the dream', but its English equivalent has a different meaning altogether.

\section{Der Traum}

In Vienna the past weighs heavy on the present. Old stone buildings squat solemn on the city streets, and brood over tombs and statues. Palace walls, staunch with age, guard longkept secrets within their gilded halls. Close to our hotel a Flakturm hunkers down; it will be there forever.

Today, through our window we see the late summer sun shoot wands of morning light across the masonry, and the treelined street below is green and shimmering. It is the first time in years that we have spent more than a weekend alone together, and this day is laid out before us like a feast. But last night's dream hangs over me; I try to shake it off, but it clings with cold moist fingers.

'Who could be upset on a day like this?' my husband asks. I tell him that I've had a dream, a very bad dream, too bad to recount. He says I must tell him, he insists, and so I do.

I enter a house. It's a familiar place, but I step tentatively, because I am an intruder. Slowly I open the door into the living room. The occupants turn to see me, and their faces register shock and distress. They gather around and press against me, preventing me from moving further inside.

I recognise these people; they are characters from my childhood and adolescence: a schoolfriend, her younger sister, and their mother. They come from England, and the mother, a doctor, is different, more worldly, than the other mothers around our way. Curiously, these people are no older than they were back then, while I am my current age.

I have to get further inside that house. I know that my daughter is inside and I have to claim her. I tell these people that I have to see my daughter.

But the doctor-mother tells me I cannot see her. 'Your daughter doesn't want to see you,' she says with her long British vowels. 'It's not good for her to see you.' Then she tells me in a voice flat with authority that I need to accept that my daughter is no longer mine, that she belongs with them now.

A door opens off the living area and I can see through into another, darker room. I can see my daughter, or the child my dream-self knows to be my daughter, in that room, propped up on a chair and wrapped in a blanket. She is small, about ten years old, not 21, as she should be now. Her pale, serious face 
is surrounded by a fluff of fine blonde hair. She looks too small, I think. Her wide eyes look steadily out from the darkness.

Emotion floods through me: panic, or frustration, or love, I can't tell which. I push past the sisters and the doctormother. I go to my child, and extend my hand to touch her. But I recoil: she looks back at me with indifference. It's not that she doesn't recognise me; it's that she doesn't care. The sisters and the doctor-mother gather around her protectively, shielding her from me.

'You should go,' the doctor-mother says.

'No,' I say. 'She is my daughter and I want her. I want to take her with me.'

'You can't do that,' the doctor-mother says. 'She isn't yours anymore. Remember?'

But I don't remember. My dream-self searches back through my memory, but nothing materialises to explain all this. There are just brief glimpses, traces that sweep past me and fade into shadows. Truth laps at my ankles, and drains away.

'She belongs here with us now, 'the doctor-mother says.

They turn away. Now I am alone with my daughter. Love and longing percolate though me, pushing me through the shadows towards her. I reach down for her, and lift her, and tuck the blanket in around her small naked body to keep her warm. Then I dash out of that room, and the next, and out of the house with my child-bundle pressed close to my chest.

I run out onto the street. They are following me. I hurry to escape from them, but I cannot find my car. Where is my car? Why isn't it here where I parked it? I keep running down the road, farther and farther. I hear the doctor-mother shouting behind me.

'You can't have her! She belongs here now, she cries 'We will tell all about you. We will tell everything. Everyone will know what you have done.'

Then a familiar paralysis creeps over me. It's an old fear that cuts to my depths and crumbles my certainties. I have done nothing, I am sure, but this is something more powerful than truth. I stumble and fall, the weight of my child suddenly heavy in my arms.

I try to move, but I am welded to the road, the doctormother's words still stinging my ears...

When I am finished with the telling, my husband puts his arms around me on the big Viennese bed. A shaft of sunlight falls across the bright white sheets. 'Don't worry,' he whispers. 'You are a good mother. Du bist eine gute Mutter.'

On one level, this piece recounts a bad dream that may be related to my sense of guilt at being away from my disabled daughter. But on a deeper level, the story deals with my failure to move beyond my own dislocation. The place, Vienna, is a place where the past - its glories and atrocities - intrudes on and often overwhelms the transient benignity of the present; here the past will not be suppressed. In the dream, I face terror at the disavowal of myself as a mother. Time and space are confused, as they are in all dreams; I find myself somewhere vaguely familiar, but in a fictional past, in a different timeframe from the other characters. Exclusion is physical, through barred doorways, but also social and psychic. Agents of the ordered social world and the authoritative world of medicine - the doctor-mother and her daughters - taunt me, and refuse my claim as a mother. My own daughter denies me. Accusations 
and the formless memory of my own transgression render me immobile, speechless.

This story emerges from my sense of liminality, from a place where the boundaries between past and present, here and elsewhere, self and other, collide and shatter. It manifests as a dream, a form in which emotions can defy containment, where forbidden memories play out, in contrast to tidier, narrative forms of storytelling. The language of dreaming unfolds through association and metaphor, and it is through this form that I speak of my disruption. I catch this dream just before it slips away, unheard and unremembered. Then, when my husband speaks to me, I am returned to the present time, to the order and tangibility of the hotel room.

\section{Conclusion}

My story reveals the deep flaws in my journey as the mother of a child with disability. In recounting this dream, I bear witness to my failure to contain my emotional experience, and re-locate myself within the sanitised boundaries offered by a tale such as 'Welcome to Holland'. The simple logic of this story fails to compel me. As such, I am exposed as an outsider among outsiders, by refusing the narratives that define my tribe.

We mothers of children with disabilities inhabit the borderlands of both disability and motherhood. We make forays across these frontiers; we shift shape as we do so, and press ourselves into the ill-fitting identities that these narratives demand. These stories set out to normalise our mothering experience, and exhort us to repress the psychic impacts of transgression and marginalisation. But the impacts of this turbulence are deep and long-term: memory traces and unnameable feelings are liable to erupt through the cracks in spite of efforts of resilience and resistance. These are the reminders of our ongoing dislocation. This is the strange country that we inhabit.

\section{Notes}

[1] It is noteworthy that variations of Kinsgley's story, such as the one cited by Rapp and Ginsberg (2001), omit this paragraph. return to text

[2] This memoir was undertaken as the creative component of my PhD in Media and Cultural Studies at Macquarie University, New South Wales, Australia. return to text

\section{Works cited}

Dura-Vila, G, S Dein, \& M Hodes 2010 'Children with intellectual disability: A gain not a loss: Parental beliefs and family life', Clinical Child Psychology and Psychiatry 15: 171-84 return to text

Dykens, EM 2005 'Happiness, wellbeing, and character strengths: Outcomes for families and siblings of persons with mental retardation', Mental Retardation 43, 5: 360-4 return to text

Edelson, M 2000 My Journey with Jake: A Memoir of Parenting and Disability, Between the Lines, Toronto return to text

Evans, K 2007 Tuesday's Child, Bantam, North Sydney return to text

Frank, AW 2004 'Moral nonfiction: life writing and children's disability', in JP Eakin (ed), The Ethics of Life Writing, Cornell University Press, Ithaca NY: 174-194 return to text 
Frank, AW 2010 Letting Stories Breathe: A Socio-narratology, Chicago University Press, Chicago return to text

Friedman, SS 1998 Mappings: Feminism and the Cultural Geographies of Encounter, Princeton University Press, Princeton NJ return to text

Goodley, D 2007 'Becoming rhizomatic parents: Deleuze, Guattari and disabled babies', Disability \& Society 22, 2: 145-160 return to text

Grant, G \& P Ramcharan 2001 'Views and experiences of people with intellectual disabilities and their families (2): The family perspective', Journal of Applied Research in Intellectual Disabilities 14: 364-80 return to text

Grant, G, P Ramcharan, \& M Flynn 2007 'Resilience in families with children and adult members with intellectual disabilities: Tracing elements of a psycho-social model', Journal of Applied Research in Intellectual Disabilities 20: 563-75 return to text

Groneberg, JG 2008 'Road map to Holland: How I Found My Way Through My Son's First Two Years with Down Syndrome, New American Library, New York return to text

Hastings, RP, K Allen, K McDermott \& D Still 2002 'Factors related to positive perceptions in mothers of children with intellectual disability', Journal of Applied Research in Intellectual Disabilities 15: 369-75 return to text

Johannesen, J 2011 No Ordinary Boy: The Life and Death of Owen Turney, Low to the Ground, Toronto return to text

Kingsley, EP 2001 [1987] 'Welcome to Holland', in SD Klein \& K Schive (eds) You Will Dream New Dreams: Inspiring Personal Stories by Parents of Children with Disabilities, Kensington Books, New York: 216-17 return to text

Kingston, AK 2007 Mothering Special Needs: a Different Maternal Journey, Jessica Kingsley, London return to text

Klein, SD \& K Schive (eds) 2001 You Will Dream New Dreams: Inspiring Personal Stories by Parents of Children with Disabilities, Kensington Books, New York return to text

Knight, K 2013 'Pregnancy and blame: what it means for mothers of children with disabilities', The Conversation (22 February): http://www.theconversation.com/ pregnancy-and-blamewhat-it-means-for-mothers-of-children-with-disabilities-12250 (accessed 18 April 2017) return to text

Landsman, G 2005 'Mothers and models of disability', Journal of Medical Humanities 26, 2/3: 121-39 return to text

Landsman, GH 2009 Reconstructing motherhood in the age of 'perfect' babies, Routledge, New York return to text

Liewicki-Wilson, C \& J Cellio (eds) 2011 Disability and Mothering: Liminal Spaces of Embodied Knowledge, Syracuse University Press, New York return to text

McKeever, P \& K-L Miller 2004 'Mothering children who have disabilities: a Bourdieusian interpretation of maternal practices', Social Science and Medicine 59: 1171-91 return to text

Moore, C 2004 George and Sam, Penguin, London return to text

Piepmeier, A 2012 'Saints, sages, and victims: endorsement of and resistance to cultural stereotypes in memoirs by parents of children with disabilities', Disability Studies Quarterly 32, 1:dsq-sds.org/article/view/3031/3058 return to text

Raca, J 2012 Standing Up for James, Clarendon Publications, London return to text

Rapp, R \& F Ginsberg 2001 'Enabling disability: rewriting kinship, reimagining citizenship', Public Culture 13, 3: 533-56 return to text

Raspberry K \& D Skinner 2007 'Experiencing the genetic body: parents' encounters with pediatric clinical genetics', Medical Anthropology 26, 4: 355-91 return to text 
Read, J 2000 Disability, the Family and Society: Listening to Mothers, Open University Press, Buckingham UK return to text

Robertson, R 2012 Reaching One Thousand: A Story of Love, Motherhood and Autism, Black Inc, Collingwood Vic return to text

Robertson, R 2011 'Writer first, mother second: the politics and ethics of motherhood memoirs', in J Conway-Herron, M Costello \& L Hawryluk (eds) The Ethical Imaginations: Writing Worlds Papers - Refereed Proceedings of the 16th Conference of the Australasian Association of Writing Programs, 2011: http://www.aawp.dreamhosters.com/wpcontent/uploads/2015/03/Robertson_0.pdf (accessed 10 April 2017) return to text

Ryan, S \& K Runswick-Cole 2009 'From advocate to activist? Mapping the experiences of mothers of children on the autism spectrum', Journal of Applied Research in Intellectual Disabilities 22: 43-53 return to text

Ryan, S \& K Runswick-Cole 2008 'Repositioning mothers: mothers, disabled children and disability studies', Disability \& Society 23, 3: 199-210 return to text

Shakespeare, T 1994 'Cultural representation of disabled people: dustbins for disavowal?' Disability \& Society 9, 3: 283-299 return to text

Shapiro J, J Blacher \& SR Lopez 1998 'Maternal reactions to children with mental retardation', in JA Burack, RM Hodapp \& E Zigler (eds) Handbook of Mental Retardation and Development, Cambridge University Press, Cambridge: 606-636 return to text

Skinner, D \& TS Weisner 2007 'Sociocultural studies of families of children with intellectual disabilities', Mental Retardation and Developmental Disabilities Research Reviews 13: 302-12 return to text

Todd, S \& S Jones 2003 “"Mum's the word!": Maternal accounts of dealings with the professional world', Journal of Applied Research in Intellectual Disabilities 16: 229-44 return to text

Trute, B, KM Benzies, C Worthington, JR Reddon \& M Moore 2010 'Accentuate the positive to mitigate the negative: Mother psychological coping resources and family adjustment in childhood disability', Journal of Intellectual and Developmental Disability 35, 1: 36-43 return to text

Turnbull, AP, JA Summers, S-H Lee \& K Kyzar 2007 'Conceptualization and measurement of family outcomes associated with families of individuals with intellectual disabilities', Mental Retardation and Developmental Disabilities Research Reviews 13: 346-56 return to text

Kathryn Knight has a PhD in Media and Cultural Studies from Macquarie University, consisting of an exegesis, in which she explored representations of mothers of children with disabilities from interdisciplinary perspectives, and a creative component, in the form of a memoir of her experience mothering a daughter with a severe disability. Kathryn has a background in professional writing and university teaching; she currently works in a management role in the disability services sector.

\section{TEXT}

Vol 21 No 2 October 2017

http://www.textjournal.com.au

General Editor: Nigel Krauth. Editors: Kevin Brophy, Enza Gandolfo \& Julienne van Loon text@textjournal.com.au 